Provided for non-commercial research and educational use only. Not for reproduction or distribution or commercial use.

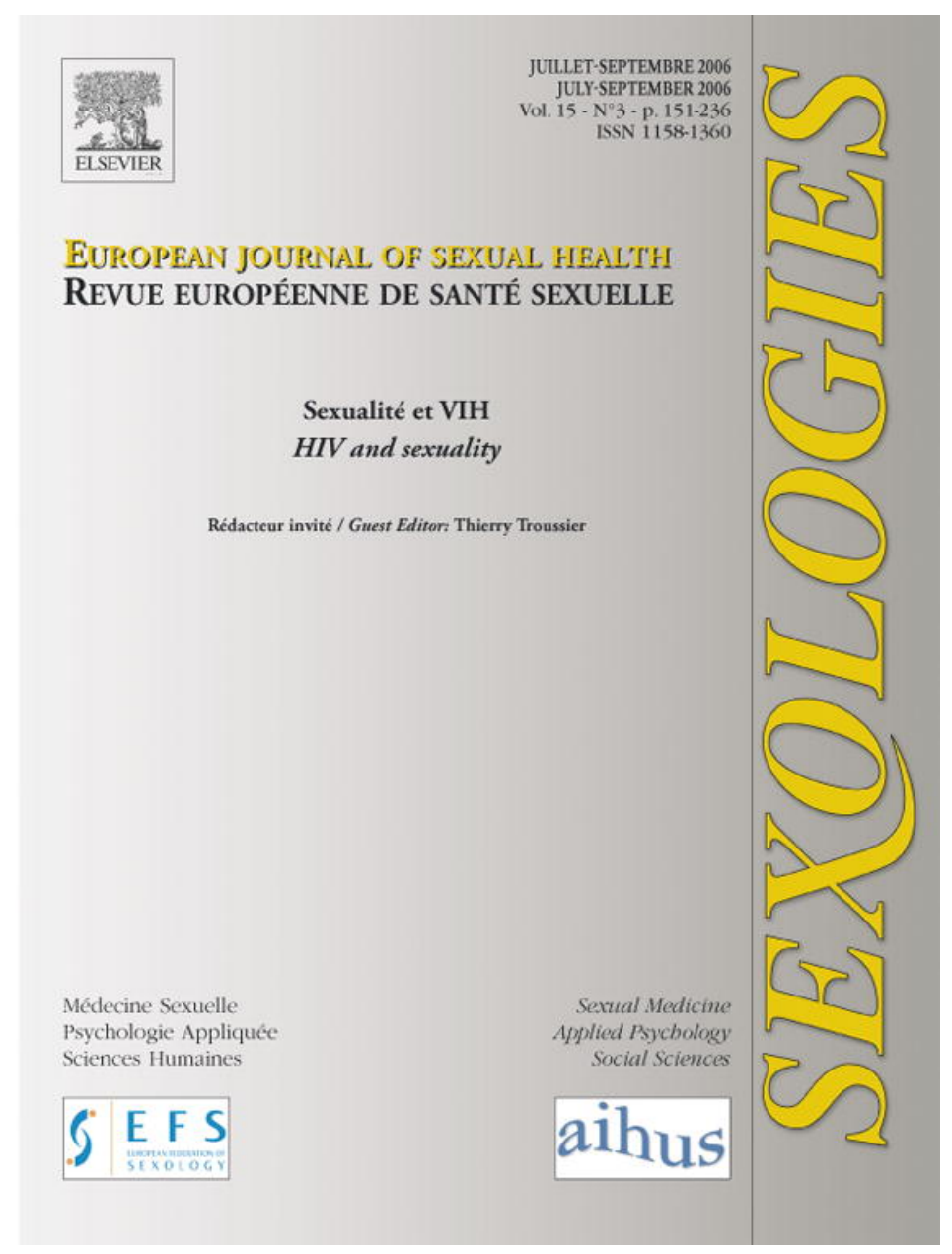

This article was originally published in a journal published by Elsevier, and the attached copy is provided by Elsevier for the author's benefit and for the benefit of the author's institution, for non-commercial research and educational use including without limitation use in instruction at your institution, sending it to specific colleagues that you know, and providing a copy to your institution's administrator.

All other uses, reproduction and distribution, including without limitation commercial reprints, selling or licensing copies or access,

or posting on open internet sites, your personal or institution's website or repository, are prohibited. For exceptions, permission may be sought for such use through Elsevier's permissions site at:

http://www.elsevier.com/locate/permissionusematerial 


\section{Sexualités et vulnérabilité au VIH en Chine, un regard anthropologique ${ }^{i s}$}

\section{Sexualities and HIV/AIDS vulnerability in China, an anthropological perspective}

\section{E. Micollier (Anthropologue à l'IRD)*}

LPED, UMR 151 IRD, université de Provence, 13331 Marseille cedex 03, France

Disponible sur internet le 02 août 2006

\author{
MOTS CLÉS \\ VIH ; \\ Sexualités ; \\ Prévention ; \\ Mobilisations sociales ; \\ Chine ; \\ Anthropologie
}

Résumé Selon une approche anthropologique, la sexualité est étudiée en tant qu'objet social et la notion de culture plurielle déclinée localement joue un rôle heuristique dans la production d'études sur des sexualités " contextualisées » dans le contexte de la propagation mondiale du sida. L'épidémie de VIH/sida, reconnue comme l'un des problèmes de santé publique les plus urgents à un niveau global, en particulier dans les pays en développement, et maladie " sociale » par ses implications et les représentations qui y sont associées, a relancé ou généré le développement, selon les pays, des études sur la sexualité en dépit du risque d'instrumentalisation de ces études par l'épidémiologie - important à évaluer dans chaque contexte et du risque associé de moralisation implicite de la sexualité par des tentatives de normalisation et de légitimation par la science. Le traitement social de l'épidémie, intrinsèquement lié à sa prise en charge médicale, a facilité la reconnaissance de la diversité des « cultures sexuelles » qui prennent forme dans un ensemble ouvert et dynamique d'interactions et de relations affectives, sociales, politiques et économiques. À la suite d'une introduction qui donne des clés théoriques, méthodologiques et sur le contexte chinois, sont abordés : 1)la transmission sexuelle du VIH et les dynamiques épidémiques ; 2 ) son inscription sociale et la situation des minorités sexuelles ; 3 ) le développement des études sur la sexualité. Le traitement de tels thèmes contribue à documenter dans un contexte spécifique le phénomène social du commerce du sexe ainsi que l'émergence et la reconnaissance de groupes minoritaires en matière d'orientation sexuelle et de leurs droits, même si elle est encore timide et limitée, et la négociation de ces groupes avec d'autres acteurs s'inscrivant dans des cadres normatifs traditionnels (la famille) ou officiels. Enfin, soulignons que dans le contexte de la prévention et de la prise en charge du $\mathrm{VIH} /$ sida en Chine, l'intérêt pour la «santé sexuelle » a un rôle heuristique dans la production récente, diversifiée et exponentielle d'études sur la sexualité et dans la défense de droits sociaux et individuels.

(c) 2006 Elsevier SAS. Tous droits réservés.

Cet article est la version révisée d'une communication présentée au colloque international « New Frontiers of Southeast Asian and Pacific Studies », Center for Asia-Pacific Area Studies, Academia Sinica, Nov. 24-25 2005, Taipei, Taiwan.

*Auteur correspondant.

Adresse e-mail : Evelyne.Micollier@up.univ-mrs.fr (E. Micollier). 


\section{KEYWORDS}

HIV;

Sexualities;

Prevention;

Social mobilisation;

China;

Anthropology

\begin{abstract}
Using an anthropological approach, sexuality is studied as a social object, and this idea which is pluralist and wide-ranging, depending location, plays the role of a heuristic in 'contextualised' studies on sexuality during a period when AIDS is spreading worldwide. The HIV/AIDS epidemic, which is recognised as one of the most pressing public health problems globally, and in particular in developing countries, and as a 'social' disease because of the implications and representations associated with it, has stimulated, or caused to be developed, studies on sexuality despite the risk that these studies will be used as a mere tool for epidemiology - which should be assessed in each context - and despite the risk associated with implicit moralisation of sexuality in terms of attempts by the scientific community to establish standards and thresholds of legitimacy for sexuality. The way the epidemic is treated in society is closely linked with medical care for it, and has facilitated recognition of the diversity of 'sexual cultures' which take shape in an open and dynamic context of affective, social, political and economic interactions and relationships. Following an introduction which provides pointers to the theory, methodology and Chinese context, the following are examined: 1) sexual transmission of HIV and the epidemic dynamic; 2) its situation within society and the position of sexual minorities; 3 ) the development of studies on sexuality. Discussion of such themes contributes to documentation, in a specific social context, the social phenomena of sexual commerce in the same way as emergence and recognition of groups of minority sexual orientation, and of their rights, although these rights are still timidly granted in a limited context, and the way in which these groups negotiate with other participants in traditional normative structures (the family) or official structures. Finally, we should note that, in the context of prevention and care of HIV/AIDS in China, the idea of 'sexual health' acts as a heuristic for studies of sexuality, which recently have been produced in ever-greater numbers and on increasingly diverse subjects, and in defending social and individual rights.
\end{abstract}

(c) 2006 Elsevier SAS. Tous droits réservés.

\section{Abridged version}

The way in which sexually transmitted diseases are considered in society may be examined using questions of risk, sexuality and social relationships between the sexes (gender). From an anthropological and 'constructionist' perspective, sexuality is a unique viewpoint from which to explore social behaviour in its many guises, in the context of the HIV/AIDS epidemic. This epidemic is recognised to be one of the most urgent threats to public health globally, and in particular in developing countries, and is considered as a 'social' disease because of its implications and connotations.

A constructivist/constructionist approach relies on identification of social and cultural factors, consideration of these factors as determiners of sexuality, and a reformulation of the body of knowledge about sexuality, in the light of the social and historical conditions under which this body of knowledge was gathered: the term 'constructivist' is used more in the fields of epistemology and theories of learning, and has a more cognitivist connotation, while the more general term 'constructionism' primarily encompasses the social dimensions of behaviour and social practices (Long, 2001: 244). The current consensus view on sexuality is that it is a social construct which is located in an open and dynamic context of emotional, social, political and economic relationships.

Setting aside the naturalistic theory of social relations between the sexes, the idea of gender arises as a pertinent way of understanding the 'structural force' (Bourdieu, 1998: $140-147)$ behind the social and symbolic inequality between men and women and in the relationships between them, including sexual relationships. However, we should also emphasise that in all societies, sexuality casts light on and is the result of economic and political (and other types of) reality, which have no direct link with sex or gender (Godelier, 2003: 194). The way in which the AIDS epidemic, and in particular its medical care, has been considered in a social context has contributed to a recognition of the diversity of 'sexual cultures', which reveals, at the same time, the unity of the human race and the diversity of its cultures. In this article, the concept of 'sexual culture' refers to a consensual model of ideas associated with sexual behaviour in a group. Underlying this model is a vision of the world and of values with regard to the nature and purpose of sexual relations. It also implies an affective model of emotional states and moral principles, aiming to institutionalise what is experienced as normal, natural, necessary or approved of by a group of participants (Herdt, 1997: 10).

The concept of 'sexual health' was discussed at a WHO conference in 1975, and refers not only to pathology arising from sexual activity and requiring care, but also to the psychological, emotional and social aspects of sexual activity; it also introduces the idea of individual or political 'responsibility' of public healthcare institutions, which ideally should develop 'sexual health' services that are suitable for the context in which they operate (Giami, 2002). Sexuality is therefore considered in terms of acts, representations and relationships which take place within the affective and sexual lives of individuals, who move in social contexts (Bajos et al., 1995). The concept of sexual health, considered as a component of reproductive health but dissociating sexuality from procreation, raises the idea of 'responsible sexuality' and the division of this responsibility among men and women (Bonnet, Guillaume, 2004: 15). When applied in the context of HIV infection and its psychological, social and economic implications, this idea of 'responsibility' obtains 
all its meaning from the constraints relating to prevention and care of this 'medical situation'. We should also emphasise that the main aspects of sexuality that are currently 'medicalised', or which arise from problems of public health, are contraception, abortion, prevention of STIs (including HIV) and of sexual abuse, and care of sexual disorders (Giami, 2002: 7).

From an interactionist perspective, contemporary Chinese society provides several examples of representations and practices that interact to produce tensions that must be managed, and values, behaviour and actions are subject to renegotiation: the first system arises from pluralist and dynamic Chinese tradition (local traditional discourse), the second was introduced by Marxist ideology and nurtured the project to construct a socialist society (official discourse), and the third reflects the global model that is producing changes in China just as it is elsewhere (local global or 'glocalised' discourse).

Ideological and behavioural models underlying sexual life of individuals are transmitted in messages from family or the State through conduits such as schools or family planning organisations and through new, uncontrollable messages from a society on the path of transition to a consumer society that is subject to economic and cultural globalisation processes. The family is an essential means of relaying official State advice, along with schools and workplaces, and can become a useful locus for sexual health education and prevention and care of STIs (Sexually Transmitted Infections) including HIV infection.

Inquiries into HIV/AIDS vulnerability in the context of a flourishing sex industry were carried out in 1997 and 1999 in southern China (Shanghai, Guangxi: Beihai resort, the Gulf of Tonkin) and in Taiwan (Taipei). The methods used relied on collecting qualitative, ethnographic data, with the aim of producing an anthropological analysis: a series of interviews with and observations of various participants in the sex industry were carried out at places where sexual transactions regularly took place; by developing longer-term relationships with female sex workers, their life stories were obtained (Micollier, 2004). In addition to these data gathered on the ground, recent Chinese academic and popularised sources on sexology and human sexual studies were gathered and analysed, and these studies helped to decode representations of social groups and individuals in this context.

Arising from these theoretical and methodological considerations were the following points: (1) sexual transmission of HIV in the context of an epidemic dynamic; (2) its situation within society and the position of sexual minorities, and (3) development of studies on sexuality in the context of collective efforts against AIDS.

\section{HIV - Sexual transmission and dynamics of the epidemic}

During the 1990s, this epidemic initially spread through sharing of infected needles by drug users, and then by the heterosexual route, and similar epidemic models were observed in Thailand, Vietnam, Burma and southern China.

Since the Chinese government started to collect more representative data on HIV/AIDS by producing better esti- mates of data in the most vulnerable groups and by using more reliable methods of estimation, the estimated number of people living with AIDS (PWHIV) has been revised downwards in 2005, bringing the number to 650,000 (between 540,000 and 760,000 , as against 840,000 in 2003) which includes 75,000 people suffering from AIDS (between $60,000$ and 80,000$)$ and the recalculated average rate of infection has fallen by half $(0.05 \%$, between $0.04 \%$ and $0.06 \%$ ); moreover, 25,000 people (between 20,000 and 30,000 ) have died of AIDS (UNAIDS, 2006). However, the number of new infections is constantly increasing (an estimated 70,000 new infections) particularly by sexual transmission (49.8\%) and through infected blood (injecting drugs: $48.6 \%$ according to UNAIDS, 2006). The number of infections by sexual transmission has increased exponentially over recent years, which confirms that there is a risk of spreading HIV into the general population: the number of HIV infections estimated to be contracted through heterosexual transmission rose to $5.5 \%$ of the total number of infections in 1997, to $10.9 \%$ in 2002 (UNAIDS, 2003) and this figure reached $19.8 \%$ in 2004 , to which should be added the 11.1 $\%$ of infections transmitted by homosexual sex (UNAIDS, 2004) which brings the rate of infection through sex to $30.9 \%$. In 2005 this figure rose to $43.6 \%$ (UNAIDS, 2006). Homosexuals are the group who are, after intravenous drug users and sex workers, most vulnerable to HIV infection. However, the extent of the epidemic among homosexuals may be masked by the fact that, according to researchers' estimations, between $80 \%$ and $90 \%$ of homosexuals marry and have heterosexual relationships with their spouses at least for procreation purposes (Kaufman and Jing, 2002; Pan, 1995, 1996; Wan, 2001, 1996; Zhou, 1996). Sex workers and their clients make up $19.6 \%$ of the total number of PWHIV and men who have sex with men (MSM) 7.3\%; among sex workers, the rate of HIV infection has risen from $0.02 \%$ in 1996 to $0.93 \%$ in 2004 (UNAIDS, 2006: 2 and 4).

Individual internal and external (cross-border) mobility, which is promoted by movement of goods and people, and by regional economic integration in east and south-east Asia, as well as mobility of participants in the sex industry (e.g. sex workers, clients, owners of various facilities used by the sex industry, procurers, smugglers, carriers, authorities) is known to be an important factor in spreading HIV. In the UNAIDS report of June 2002, which was notable in that it really alerted local and international bodies to the extent of the epidemic risk of HIV in China, other factors were mentioned, particularly a very neglected public health system in rural areas, which has the immediate consequence that many people are excluded from the prevention and care system; in addition, the report pointed out that PWHIV are significantly stigmatised, and that ethnic minority groups in China (56 such groups are officially registered) are populations more vulnerable to HIV infection, a vulnerability increased by poor socio-economic conditions (poverty).

\section{Situation of sexually transmitted infection within society and the position of sexual minorities}

In the context of the risk of HIV, the social significance of the resonance of trade in sexual activity should be emphasised, within the framework of the local sexual culture: this 
trade, understood as a social practice and a 'mark of social distinction' for men, does not generate head-on contradiction or paradoxical restriction of the role of women in the context of local family structures and norms, but rather it generates tensions that need to be managed, and a sexual culture emerges that is implicitly structured by the sex trade (Micollier, 2004: 3-22). The Confucian principles and values of the family do not permit pleasure-oriented sexuality within the family unit; instead, conjugal sexuality is oriented towards reproduction. Until the 1930s, erotic desire-led sexuality was lived outside the family setting, particularly in the courtesan system and other categories of sex workers. There is a real social stratification of courtesans, which mirrors that of their clients, and this model was well-documented in 1930s Shanghai, by the social historical studies of Henriot (1997) and Hershatter (1997). As in many societies, 'sexuality for desire' is distinguished from 'sexuality for reproduction' and 'desire is not recognised as the departure point for a legitimate union between the sexes' (Godelier, 2003: 195).

Relatively independent initiatives, aiming principally to prevent HIV and which generally operate in the context of public health departments and academic institutions, have succeeded in mobilising the male homosexual community in Chinese cities: Beijing, which is estimated to have the largest number of actively homosexual men in China; Shanghai, Canton; Xi'an in north-west China and Shenyang, Harbin and Dalian in Manchuria (North East). According to statistics from the public security forces (police), $1 \%$ of the male population of Beijing is homosexual, which is a conservative figure that is nonetheless acceptable for Li (1992, 1998a, 1998 b) who carried out sociological studies on homosexuality, but this figure is too conservative for other specialist sociologists (Pan, 1995, 1996) and activist gay researchers such as Zhou $(2000,2001)$ who proposes a rate of between $3 \%$ and $5 \%$; and in Shanghai, the official estimate is $0,5 \%$.

In China, homosexuality was decriminalised in 1997 and 'de-pathologised' in 2001, under pressure from American psychiatric and psychological associations and in accordance with the WHO International Classification of Diseases (ICD), and certainly also because Chinese society has shown increasing tolerance towards homosexual people, who are also becoming more visible. Homosexuality, until this point, had been included on the 'Chinese list of mental disorders'. In Asia, only four countries - Japan, Korea, Taiwan and the People's Republic of China (including Hong Kong) have officially stopped considering homosexuality as a psychiatric disorder. AIDS projects have stimulated the development of gay/lesbian movements, or have at least made them more visible in major Chinese cities: in the 1990s, AIDS activism acted to reveal and defend these movements.

\section{Development of studies on sexuality and human sexuality studies}

The major quantitative studies, which follow more or less the same model as the Kinsey report, should be distinguished from sociological studies based on collection of quantitative (and possibly qualitative) data, which in turn should be distinguished from more detailed sociological or ethnolo- gical studies, which use qualitative data as the principal material for analysis. The national sexuality report, published in 1992, which is commonly referred to as the Chinese Kinsey report, and the critical analysis that has been done of it, shed light on the plurality of discourse about sexuality. Unlike recent reports published in other countries, it does not draw a direct link with sexual transmission of HIV, as in the early 1990s, when the study was carried out, the epidemic risk of AIDS was denied. However, STIs including AIDS had been noted as problems arising from sexuality and that should be treated in the context of health and social care. The Liu report (Liu et al., 1992 [Chinese version]/Ng, Manlun and Erwin J. Haeberle 1997 [English translation]) is based on a sexual behaviour survey of 20,000 people carried out in China in 1989 and 1990. The aim of this enquiry was to identify and clarify problems linked to human sexuality in contemporary China. Sexuality in adolescents and young people, control and management of sexuality, and the rapid spread of STIs (and possibly HIV) in the 1990s are included in these problems. The 'Centre for sociological research on sexuality in Shanghai', directed by Liu, benefited from the favourable political and social climate in the late 1980 s, and organised this survey, which was carried out in the context of official organisations.

During this period of reform and increased openness, social and biological problems associated with sexuality and the need for sexual health education were officially recognised and became subsidised. Official discourse was also emphasising 'the historical need to confront and resolve problems that are difficult to accept, such as the development of the sex trade and the spread of STIs' (Liu et al., 1992: 21).

During the late 1980s, doctors in Beijing such as Dr Wu (1988), then director of the Academy of Medical Sciences, and Professor Ruan (1991) from the Medical University injected dynamism into sexological research, and two sociological research institutes have now been specialising in such sexuality studies for the past couple of decades; one was founded by Liu in Shanghai and the other by Pan in Beijing (Institute for Gender and Sexuality Research).

Moreover, sexuality has become a discreet but dynamic area of reformed China: according to Pan (1993: 5), the scientific discourse of sexology has produced a neutral language in which sexuality and sex education can be expressed, which facilitates communication in this area; he notes that more than 200 books about sexology were in circulation in 1991, versus only six in 1979. He links diversification, visibility and even the increase in sexual activity to many factors: of these, he considers changes in living conditions to be significant, namely moving away from courtyard-based houses into apartments in blocks where private life is better separated, in spatial terms, from collective life (Pan, 1993: 13).

\section{Conclusion}

As shown by official studies such as the Liu report (1992), or Pan (1993) on sexual behaviour, or more balanced and problematised studies on sexual representations and practice (for example Li, 1998a, and her qualitative study 1998b), it is necessary to 'contextualise' sexualities, while avoiding 
'culturalisation' of sexuality, in order to optimise prevention and care action to combat the sexual epidemic of HIV/AIDS.

In China, as elsewhere, the emergence and recognition of minority groups distinguished according to sexual orientation, and of the rights of these groups, even though these rights are still only timidly granted in a limited context, and the way in which these groups negotiate with other participants in traditional normative contexts (the family) or official contexts, have been facilitated by collective antiAIDS action by civil and official bodies, although this action has been somewhat delayed due to denial by the authorities of the existence of an epidemic at all for a certain period.

In the context of prevention and care of HIV/AIDS in China, the idea of 'sexual health' acts as a heuristic for studies on sexuality, which recently have been produced in ever-greater numbers and on increasingly diverse subjects, and in defending social and individual rights. Such a concept is effectively a useful pragmatic component of negotiations of these rights with official institutional bodies, and can indeed be indispensable if this discussion is to take place at all, even if it nevertheless should be noted that some sexological studies, particularly emerging from the medical field, reveal that the notion of 'sexual health' is being used as a political tool (McMillan, 2006), and that these studies, in terms of their ethical framework and effectiveness at serving public health, are controlled by dubious official action and discourse. As Giami (1996) showed in studies carried out on HIV/AIDS in France, we should note that, in the same context in China, an 'epidemiological construction of sexuality' emerges, or continues out of the long history of modernisation and normalisation of sexuality in Chinese society (Dikötter, 1995, 2000) and this appears to be a new product of ideological interference which links science (represented here by the fields of epidemiology and public health), morality and sexuality.

\section{Version longue}

\section{Introduction}

\section{Jalons théoriques et contextualisation}

L'inscription sociale de la transmission sexuelle peut être éclairée à l'aide d'un questionnement construit autour des notions de risque, de sexualité et des rapports sociaux de sexe (genre). Selon Giami (1991), « le phénomène du sida fait apparaître des problématiques nouvelles dans le champ de la sexualité : les réseaux de partenaires sexuels et la notion de risque, qui constituent la marque d'une évolution des constructions sociales de la sexualité ». Dans une perspective anthropologique et « constructioniste », la sexualité est un site privilégié pour explorer le social dans ses multiples aspects dans le contexte de l'épidémie de $\mathrm{VIH} /$ sida. Cette épidémie est reconnue comme l'un des problèmes de santé publique les plus urgents à un niveau global, en particulier dans les pays en développement, et comme une maladie « sociale » par ses implications et les représentations qui y sont associées. Deux approches théoriques - essentialiste ou constructiviste-constructioniste offrent un cadre pour les études sur la sexualité. Les approches essentialistes sont fondées sur l'hypothèse que les fac- teurs biologiques sont déterminants et le substrat dans ce qui constitue l'humain, l'homme et la femme. Une approche constructiviste-constructioniste s'appuie sur l'identification des facteurs sociaux et culturels les considérant comme déterminants dans la sexualité et reformule le corpus de connaissances relatives à la sexualité en s'interrogeant sur le contexte social et historique de la production de ce savoir : le terme " constructiviste » est davantage utilisé dans les champs de l'épistémologie et des théories de l'apprentissage en ajoutant une tonalité cognitiviste à la définition alors que le terme plus général de " constructionisme » embrasse avant tout les dimensions sociales du comportement et de la pratique sociale (Long, 2001). La sexualité est aujourd'hui considérée de manière plus consensuelle comme un construit social qui se constitue dans un ensemble ouvert et dynamique d'interactions et de relations affectives, sociales, politiques et économiques. Dès que la théorie naturelle des rapports sociaux de sexe est écartée, la notion de genre apparaît comme une catégorie pertinente pour appréhender la «force de la structure » (Bourdieu, 1998) face à l'inégalité sociale et symbolique entre hommes et femmes et dans leurs relations y compris sexuelles. Cependant, soulignons aussi que dans toutes les sociétés, la sexualité éclaire et résulte de réalités économiques, politiques, etc., qui n'ont aucun lien direct avec le sexe ou le genre (Godelier, 2003). Le traitement social de l'épidémie de sida, associé à sa prise en charge médicale, a contribué à la reconnaissance de la diversité des « cultures sexuelles » révélatrice à la fois de l'unité de l'homme et de la diversité des cultures. Dans cet article, le concept de « culture sexuelle » réfère à un modèle consensuel d'idées associées au comportement sexuel dans un groupe. Ce modèle est sous-tendu par une vision du monde, de valeurs concernant la nature et la finalité des relations sexuelles. Il implique aussi un modèle affectif d'états émotionnels et des principes moraux visant à institutionnaliser ce qui est ressenti comme normal, naturel, nécessaire ou approuvé par un ensemble d'acteurs (Herdt, 1997).

Discuté lors d'une conférence de l'OMS en 1975, le concept de «santé sexuelle » réfère non seulement aux pathologies liées à la vie sexuelle et nécessitant une prise en charge mais encore aux composantes psychologiques, affectives et sociales des relations sexuelles; il introduit aussi la notion de « responsabilité » individuelle ou politique des institutions de santé publique qui devraient idéalement développer des services de "santé sexuelle » adaptés au contexte (Giami, 2002). La sexualité est alors reconnue en termes d'actes, de représentations et de relations qui s'inscrivent dans les trajectoires affectives et sexuelles d'individus insérés dans des cadres sociaux (Bajos et al., 1995). La santé sexuelle, en tant que composante de la santé de la reproduction mais dissociant la sexualité de la procréation, fait émerger l'idée de "sexualité responsable » et de partage de cette responsabilité entre hommes et femmes (Bonnet et Guillaume, 2004). Appliquée au contexte de l'infection par le $\mathrm{VIH}$ et de ses implications psychologiques, sociales et économiques, cette notion de « responsabilité » prend tout son sens face aux contraintes de la prévention et de la prise en charge de cette « situation médicale ». Soulignons en outre que la prévention des IST (infections sexuellement transmissibles) incluant le VIH est l'un des princi- 
paux aspects de la sexualité qui sont aujourd'hui « médicalisés » et qui relèvent des problèmes à gérer pour la santé publique, les autres étant la contraception et l'avortement, la prévention des abus sexuels, et le traitement des troubles sexuels (Giami, 2002).

Selon une approche interactionniste, la société chinoise contemporaine donne à observer plusieurs systèmes de représentations et de pratiques qui interagissent-produisant des tensions à gérer et des négociations incontournables au niveau des valeurs, des comportements et des actions : un premier système émane de la tradition chinoise plurielle et dynamique (discours local traditionnel), le second fut introduit par l'idéologie marxiste et a nourri le projet de construction d'une société socialiste (discours officiel), le troisième reflète le modèle global qui induit des changements en Chine comme ailleurs (discours local global ou « glocalisé »).

Les modèles idéologiques et comportementaux qui soustendent la vie sexuelle des individus sont transmis par des messages émanant de la famille, de l'État avec des relais comme l'école ou la planification familiale et par des nouveaux messages incontrôlables émanant d'une société en transition vers une société consumériste soumise à des processus de globalisation économique et culturelle. Dans les sociétés de tradition confucéenne, la famille est l'unité sociale élémentaire et générique, la matrice de toute forme d'organisation sociale, le premier lieu d'apprentissage et de gestion de toute relation humaine. Lieu privilégié d'apprentissage pour ses jeunes membres, elle est un lieu d'éducation pour les membres des autres générations. Relais essentiel des consignes officielles de l'État aux côtés de l'école et des sites de travail, le contexte familial est le cadre normatif, traditionnel et accepté par tous, de communication avec les femmes. Il pourrait devenir un lieu privilégié pour des interventions visant à l'éducation à la santé sexuelle, à la prévention et à la prise en charge des IST incluant l'infection à VIH.

Comme dans d'autres pays asiatiques en développement, le déni de l'épidémie de sida pendant plus d'une décennie (1985-1996) par les acteurs officiels est expliqué par de nombreux facteurs structurels et conjoncturels. Parmi eux, les valeurs associées aux modèles traditionnels chinois et socialiste sont des facteurs explicatifs. Le silence normatif résultant du déni officiel et populaire pourrait renvoyer au complexe de la préservation de la «face ", un mode de comportement adopté dans les interactions interpersonnelles qui a pour objectif de gagner l'approbation sociale. Parce qu'elle prescrit une manière de vivre et de se percevoir, la «face » met en jeu une conscience partagée du risque d'un contact social qui conduit les individus à se soutenir les uns les autres pour préserver l'image publique de tous les interactants (Zheng, 1995 ; Kipnis, 1995). Dans les années 1990, une pression globale s'est démultipliée face à l'urgence épidémique et a contribué à briser ce silence consensuel. De plus, dans les années 2000, les enjeux économiques autour des risques épidémiques de SRAS (syndrome respiratoire aigu sévère) et de grippe aviaire ont réussi à mobiliser les acteurs officiels pour des actions rapides et une gestion optimisée des risques épidémiques quels qu'ils soient, une mobilisation dont l'épidémie de $\mathrm{VIH} /$ sida, maladie chronique, bénéficie aujourd'hui.

\section{Méthode}

Des enquêtes sur la vulnérabilité au VIH/sida dans le contexte d'une industrie du sexe florissante furent conduites en 1997 et en 1999 en Chine du sud (Shanghai, Guangxi : site de Beihai, golfe du Tonkin) et à Taiwan (Taipei). La méthodologie s'appuyait sur le recueil de données qualitatives de type ethnographique avec pour objectif de produire une analyse anthropologique : une série d'entretiens et d'observations auprès de divers acteurs de l'industrie du sexe ont été menés sur des sites où se pratiquaient régulièrement des échanges sexuels marchands ; des récits de vie de travailleuses du sexe ont été collectés par le développement de relations privilégiées à moyen terme (Micollier, 2004). À ces données de terrain, s'ajoutent le recueil et l'analyse de sources chinoises récentes académiques et populaires sur la sexologie et les études en sciences humaines de la sexualité contribuant à décoder les représentations des groupes sociaux et des individus dans ce domaine.

À la suite de ces éléments théoriques et méthodologiques, sont abordés les points suivants :

- la transmission sexuelle du VIH dans le contexte des dynamiques épidémiques ;

- son inscription sociale et la situation des minorités sexuelles;

- le développement des études sur la sexualité dans le contexte des mobilisations collectives face au sida.

\section{Dynamiques épidémiques et transmission sexuelle du VIH}

En Asie et dans le Pacifique, 8,3 millions de personnes seraient infectées par le VIH portant le taux de séroprévalence moyen en population générale à 0,4 \% (UNAIDS, 2006). Dans les années 1990, l'épidémie s'est propagée dans une première phase par le partage de seringues infectées utilisées par les usagers de drogue par injection, puis par voie hétérosexuelle, suivant des modèles épidémiques identiques en Thaïlande, au Vietnam, en Birmanie et en Chine du sud. En 2003, on estimait que, $840000 \mathrm{PvVIH}$ (personnes vivaient avec le $\mathrm{VIH}$ ), 80000 patients étaient malades du sida et que le taux de séroprévalence moyen en population générale s'élevait à 0,1\% (UNAIDS, 2004). Depuis 2003, des personnes ont été testées séropositives dans toutes les provinces, régions autonomes et municipalités, montrant une extension géographique et à la population générale de l'épidémie (Chen et al., 2004, UNAIDS 2006).

Depuis que le gouvernement recueille des données plus représentatives sur le $\mathrm{VIH} /$ sida, en produisant de meilleures estimations sur les populations les plus vulnérables et en utilisant des méthodes d'estimation plus fiables, le nombre estimé de PvVIH a été revu à la baisse en 2005, portant ce nombre à 650000 (entre 540000 et 760 000) incluant 75 000 personnes malades du sida (entre 60000 et 80000 ) et le taux de séroprévalence moyen recalculé pour être diminué de moitié $(0,05 \%$, entre 0,04 et $0,06 \%)$; par ailleurs, 25000 personnes (entre 20000 et 30000 ) seraient décédées du sida (UNAIDS, 2006). Cependant, le nombre de nouvelles infections est en augmentation constante (70 000 nouvelles infections estimées) en particulier par transmis- 
sion sexuelle $(49,8 \%)$ et par voie sanguine (usage de drogue par injection : 48,6\%) (UNAIDS, 2006).

Bien que la majorité des personnes recensées séropositives aient été infectées par voie sanguine - par injection de drogue avec des seringues contaminées mais aussi par injection et manipulation du sang infecté dans le cadre des structures sanitaires suite à un trafic de vente du sang de grande ampleur (Haski, 2005) - le nombre d'infections par voie sexuelle s'accroît de manière exponentielle ces dernières années, un indicateur qui confirme le risque de propagation du VIH en population générale : le nombre d'infections par le VIH recensées contractées par voie hétérosexuelle s'élevait à $5,5 \%$ du nombre total en 1997, à $10,9 \%$ en 2002 (UNAIDS, 2003), et atteint 19,8 \% en 2004 auquel il faut ajouter $11,1 \%$ d'infections transmises par voie homosexuelle (UNAIDS, 2004) portant le taux d'infection par voie sexuelle à $30,9 \%$. En 2005, il s'élèverait à 43,6 \% (UNAIDS, 2006).

En 2004, le taux de séroprévalence parmi les travailleu(r) ses du sexe, deuxième groupe vulnérable à l'infection par le VIH après les usagers de drogue par voie intraveineuse, est estimé en moyenne à 0,93\% (UNAIDS, 2006), soit plus de dix fois supérieur au taux en population générale alors qu'il aurait été de 0,02 \% en 1996.

L'ampleur de l'épidémie homosexuelle - les hommes qui ont des relations sexuelles avec des hommes (MSM) constituant le troisième groupe vulnérable - pourrait être masquée par le fait que, selon les estimations des chercheurs, entre 80 et $90 \%$ des homosexuels se marient et ont des rapports hétérosexuels avec leur conjoint(e) au moins pour procréer (Kaufman et Jing, 2002 ; Pan, 1995, 1996 ; Wan, 1996, 2001 ; Zhou, 1996). Les travailleu(r)ses du sexe et leurs clients constituent 19,6\% du nombre total de PvVIH et les MSM 7,3 \% (UNAIDS, 2006).

Rappelons que les jeunes âgés de 10 à 24 ans représentent $26 \%$ de la population chinoise totale, soit 327 millions de personnes selon le recensement de l'an 2000, un nombre qui permet de mesurer l'importance des études sur la sexualité des jeunes face au risque d'IST et de VIH/sida. De plus, la prévalence des rapports prémaritaux oscille entre 44 et $91 \%$ selon des statistiques récentes de l'Association chinoise du planning familial (Xinhua, 2003) : le directeur de l'association souligne que les activités sexuelles des personnes non mariées et leurs connaissances en matière de sexualité ne sont pas prises en compte dans les enquêtes nationales sur la population et la santé. Les programmes de santé sexuelle ne sont toujours pas dirigés vers les jeunes non mariés, ce qui représente une grave lacune en matière de prévention IST-sida et d'éducation sexuelle.

La mobilité interne et externe (transfrontalière) des individus, favorisée par la circulation des biens et des personnes, et par l'intégration des économies à une échelle régionale en Asie de l'Est et du Sud-Est ainsi que celle des acteurs de l'industrie du sexe (travailleur(se)s du sexe, clients, propriétaires des divers espaces où se développe l'industrie du sexe, proxénètes, passeurs, transporteurs, autorités, etc.), est reconnue comme un facteur important de propagation du VIH. Dans le rapport de l'Onusida de juin 2002, qui a eu le mérite de vraiment alerter les acteurs locaux et internationaux en soulignant l'ampleur du risque épidémique de VIH en Chine, étaient mentionnés d'autres facteurs tels qu'un système de santé publique très dégradé en premier lieu en milieu rural avec pour conséquence immédiate l'exclusion de nombreuses personnes du système de soins et de prévention, de graves phénomènes de stigmatisation à l'encontre des PvVIH et au niveau de la vulnérabilité des groupes de population, l'appartenance à des groupes ethniques minoritaires de Chine (56 groupes officiellement recensés). Dans celui de 2006 (p.5), sont ajoutés encore d'autres facteurs de propagation, en outre l'augmentation des conduites sexuelles à risques et du nombre des personnes infectées par des IST.

Dans certaines localités du Yunnan, du Xingjiang et du Henan, provinces les plus affectées, l'épidémie se généralise, avec un nombre d'infections par voie sexuelle et de femmes contaminées qui s'accroissent rapidement ces dernières années (UNAIDS, 2004), ainsi qu'un taux de séroprévalence supérieur à $1 \%$ chez les femmes enceintes et celles qui sont dépistées lors de l'examen clinique prémarital obligatoire (UNAIDS, 2006).

La vente du sang et de produits sanguins contaminés à des structures sanitaires avait été dénoncée dans la presse internationale en 2001 (Rosenthal, 2001) : elle était organisée par des chefs maffieux, un trafic qui a généré une explosion épidémique d'infections par le VIH par voie sanguine dans les régions rurales du centre de la Chine, en particulier dans le Henan. Bien que le nombre de personnes recensées infectées par le VIH via le commerce du sang et du plasma constitue encore le groupe dominant, ce mode de transmission reste peu significatif en termes de prospective épidémique étant donné que la plupart des infections se sont produites avant 1996.

\section{Prévention du VIH et inscription sociale de la transmission sexuelle}

\section{Un commerce sexuel prospère et multiforme}

Le commerce du sexe en tant que phénomène social redevient visible et florissant dans la Chine des réformes, alors qu'il était dénié, éradiqué ou dissimulé pendant les décennies maoïstes dans le cadre d'une politique de rééducation par le travail fondée sur des principes moraux visant à la construction d'une société socialiste moderne. Pourtant, comme dans de nombreux pays, le commerce du sexe et la fréquentation des travailleu(r)ses du sexe restent strictement interdits par le code pénal. Dans le cadre d'un arrêté de 1991, une peine de six mois à deux ans de « rééducation par le travail » peut être appliquée à ces travailleu(r)ses et à leurs clients, mais ces dispositions juridiques demeurent sans effet. Les examens médicaux visant au dépistage des IST-VIH sont obligatoires lors de la détention des travailleu (r)ses du sexe. Les activités de prévention du VIH doivent être dirigées vers les clients et les managers de bordel aussi bien que vers les travailleu(r)ses du sexe et s'appuyer sur la connaissance des aspects socioculturels du commerce sexuel, tels que son organisation impliquant tous les acteurs de l'industrie du sexe (Huang et al., 2004) ou les spécificités locales des lieux d'exercice, de la stratification sociale parmi les travailleu(r)ses, leur perception du risque d'infection par le VIH et de l'usage du préservatif (Rogers et al., 2002). 
Face au risque de $\mathrm{VIH}$, la signification sociale de la prégnance des échanges sexuels marchands mérite d'être soulignée dans le cadre de la culture sexuelle locale : ces échanges, appréhendés comme pratique sociale et « marque de distinction » pour les hommes, ne génèrent pas de contradiction frontale ou d'injonction paradoxale autour du rôle de la femme dans le contexte de la structure et des normes familiales locales mais des tensions à gérer et l'émergence d'une culture sexuelle implicitement structurée par le commerce sexuel (Micollier, 2004). Les principes et les valeurs de la famille confucéenne n'autorisent pas le développement d'une sexualité pour le plaisir dans le cadre de l'institution familiale, orientant la sexualité conjugale vers la reproduction. Jusque dans les années 1930, la sexualité érotique initiée par le désir se vit hors du contexte familial en outre dans le cadre du système des courtisanes et autres catégories sociales de travailleuses du sexe : il existe une véritable stratification sociale des courtisanes en miroir de celle des clients, un modèle bien documenté dans le Shanghai des années 1930, par les études d'histoire sociale de Henriot (1997) et de Hershatter (1997). Comme dans de nombreuses sociétés, la « sexualité pour le désir » est distinguée de la « sexualité pour la reproduction » et « le désir n'est pas reconnu comme le point de départ d'une union légitime entre les sexes » (Godelier, 2003).

En Chine contemporaine, ont été identifiées sept catégories hiérarchisées de travailleuses du sexe reflétant la stratification sociale de la clientèle :

- en haut de la pyramide, la seconde épouse ;

- la personne recrutée pour un voyage d'affaires ou pour une période plus longue ;

- la femme escorte, dans les karaokés, les discothèques et les bars restaurants, dont les services visent à l'excitation sexuelle et aux jeux érotiques aboutissant ou non à des rapports sexuels;

- la femme qui réside dans une chambre d'hôtel et qui sollicite les clients par téléphone pour un rapport sexuel unique ;

- la femme employée dans les salons de coiffure et les salons comme masseuse ou shampooineuse peut éventuellement offrir des services sexuels;

- la personne qui « fait le trottoir» trouve ses clients dans les lieux récréatifs ;

- enfin, forme d'exploitation totale, dans les foyers de travailleurs migrants, "l'épouse collective », rémunérée pour des services variés y compris sexuels (Pan, 1999, 2004).

La situation des travailleurs du sexe est beaucoup moins documentée dans les études : des jeunes gens, appelés « money boy » en anglais ou « petit monsieur » (shaoye) en chinois vendent des services sexuels à une clientèle exclusivement masculine. Ces jeunes hommes, d'origine rurale et souvent peu éduqués, seraient environ 20000 à exercer dans les bars des grandes villes du nord de la Chine (Pékin, Harbin, Shenyang) (Pan, 2005, communication personnelle).

De plus, selon des données de la surveillance nationale, $11 \%$ des usagers de drogue par injection s'engagent dans des conduites sexuelles à haut risque qui ont un impact sur leur propre vulnérabilité et qui génèrent une accélération de la propagation du VIH au sein des groupes les plus vulnérables (les usagers de drogue par injection, les travailleu(r) ses du sexe et leurs clients) (UNAIDS, 2006).

\section{Émergence et « coming out » social des groupes gay-lesbiens-queer ${ }^{1}$}

Des initiatives relativement indépendantes ayant pour objectif principal la prévention du VIH et généralement opérationnelles dans le cadre de départements de santé publique et d'institutions académiques ont réussi à mobiliser la communauté homosexuelle masculine dans les grandes villes chinoises : Beijing où le nombre d'hommes ayant des pratiques homosexuelles est estimé le plus important de Chine ; Shanghai, Canton ; Xi'an au nord-ouest de la Chine et Shenyang, Harbin et Dalian en Mandchourie (Nord-Est). Selon les statistiques du bureau de la sécurité publique (police), $1 \%$ de la population masculine de Beijing serait homosexuelle, un taux un peu conservateur mais acceptable selon Li (1992, 1998a, 1998b) qui a conduit des études sociologiques sur l'homosexualité, un taux très conservateur selon d'autres sociologues spécialistes de la sexualité (Pan, $1995,1996)$ et des chercheurs activistes gay tels que Zhou $(2000,2001)$ qui propose un taux entre 3 et $5 \%$; à Shanghai, il s'élèverait à $0,5 \%$.

Les groupes associatifs ainsi formés ont une existence marginale et précaire. En outre, certains ont dû retourner à la clandestinité après de courtes périodes d'existence formelle. Les responsables et les coordinateurs de telles associations rencontrent des difficultés à retrouver un emploi à cause de leur engagement dans la lutte contre le sida et de leur association avec les groupes homosexuels (A human rights in China Report, 1997). Des lignes téléphoniques d'urgence gérées par des volontaires gays et des experts du planning familial et de la santé publique fonctionnent dans 13 villes chinoises (incluant les villes suscitées) : l'objectif étant d'approcher les hommes homosexuels, de les informer sur les IST et le sida et de proposer une aide psychologique (Xinhua, 2003).

En Chine, l'homosexualité fut dépénalisée en 1997 et « dépathologisée » en 2001 sous la pression des associations psychiatriques et psychologiques américaines et conformément à la classification internationale des maladies de l'OMS (ICD), aussi sûrement parce que la société chinoise montrait relativement plus de tolérance envers les personnes homosexuelles qui devenaient également plus visibles. Elle apparaissait jusqu'à cette date dans la « classification chinoise des désordres mentaux ». En Asie, seuls quatre pays - le Japon, la Corée, Taiwan et la Chine populaire (incluant Hongkong) - ont cessé officiellement de considérer l'homosexualité comme un trouble psychiatrique.

Dans les pays occidentaux où l'épidémie de sida était largement devenue une épidémie homosexuelle, « la situation épidémique a marqué profondément et durablement l'expérience sociale et la construction identitaire de l'homosexualité, aussi bien masculine que féminine... » (Broqua et al., 2003). Bien que cette situation diffère en général dans les pays en développement en n'étant pas une épidémie homosexuelle, la lutte contre le sida a stimulé le développement

\footnotetext{
1 Section révisée de Micollier (2005a).
} 
des mouvements gay-lesbiens ou du moins a favorisé leur visibilité dans les grandes métropoles de Chine : dans les années 1990, l'activisme antisida a agi comme un révélateur et un défenseur de ces mouvements. Son rôle fut moteur dans l'émergence de groupes discrets qui se constituent en réseaux virtuels relayés par des lieux de rencontre, des forums de discussion et d'information bien réels - par exemple, certains bars et salons de Beijing même s'ils sont périodiquement fermés suite à des interpellations policières et réouverts ailleurs dans la capitale.

Pour comprendre les dynamiques locales concernant la défense des droits, la visibilité et le « coming out »des groupes homosexuels, rappelons que les pratiques homosexuelles ont une inscription sociale locale et tendent à s'adapter au cadre de la famille chinoise qui représente toujours l'institution la plus stable du monde chinois. Le terme «pratiques homosexuelles» est retenu plutôt que le terme « gay » qui fait référence à la construction identitaire associée aux pratiques parce que selon les enquêtes sur la sexualité (Liu et al., 1992 ; Liu, 1994 ; Pan, 1995, 1996), la grande majorité des homosexuels de Chine ne se reconnaît pas dans une identité de minorité sexuelle. La préoccupation d'être un père et un mari pour respecter le devoir d'amour filial envers les parents et d'assurer une descendance aux ancêtres étant très prégnante, ils décident de se marier et de procréer, le mariage étant avant tout une institution sociale qui assure la reproduction biologique et sociale. Le problème de l'orientation sexuelle qui implique une catégorisation des personnes selon le genre de leur objet érotique ne se posait pas dans la civilisation chinoise : la distinction entre hétérosexuels, homosexuels et bisexuels n'existait pas (Zhou, 2001). L'activité sexuelle entre personnes du même sexe en Chine traditionnelle et les représentations qui y étaient associées, sont aujourd'hui documentées (Hinsch 1990, Vitiello 2002, Sang, 2003) : le rôle essentiel de la famille dans la vie quotidienne des individus rendait obligatoire le mariage et la procréation indépendamment de l'orientation sexuelle.

Aujourd'hui, les histoires de vie rapportées par Zhou (1997) et Rofel (1999) montrent que les homosexuels chinois négocient une tolérance sociale et familiale tout en adhérant à un modèle familial au fondement de la structure sociale, des normes et des valeurs. Les organisations gaylesbiennes adoptent des stratégies de reconnaissance de leurs droits moins conflictuelles face à la tradition et à l'État postsocialiste que celles des mouvements occidentaux, un mode de gestion « à la chinoise » des problèmes sociaux par les mouvements revendicatifs : les organisations locales engagées dans l'action sociale composent avec les autorités politiques ou symboliques en évitant la confrontation directe.

En outre, la question de l'identité sexuelle au cœur des revendications du mouvement gay-lesbien-queer international initié par les organisations occidentales, est moins centrale, voire sa pertinence discutée dans les groupes chinois : par exemple, l'acceptation du mariage et de la reproduction dans la négociation avec les parents est une manière de concilier l'amour filial avec une orientation individuelle en matière de désir érotique. Rofel (1999) évoque la parentalité et la filiation gay (gay kinship) : s'appuyant sur l'analyse de discussions de salon dans des bars homosexuels péki- nois, elle souligne que le maintien de bonnes relations avec les parents s'établit par le mariage dans la perspective d'avoir un fils pour assumer la responsabilité de donner une descendance à la famille ou au lignage et apparaît comme une préoccupation essentielle dans les débats.

\section{Développement des études sexologiques et en sciences humaines de la sexualité ${ }^{2}$}

On distingue les grandes études quantitatives chinoises suivant plus ou moins le modèle du rapport Kinsey, des études sociologiques fondées sur le recueil de données quantitatives et rarement qualitatives, enfin des études sociologiques ou ethnologiques, plus rares, qui utilisent les données qualitatives comme matériel principal de l'analyse. Le rapport national sur la sexualité paru en 1992, couramment évoqué comme le rapport Kinsey chinois, et les analyses critiques par d'autres chercheurs donnent un éclairage significatif de la pluralité des discours sur la sexualité. À la différence des rapports récents publiés dans d'autres pays, il n'a pas de lien direct avec la transmission sexuelle du VIH puisque au début des années 1990, quand l'enquête a été menée, le risque épidémique de sida était dénié. Cependant, les IST incluant le sida avaient été retenues comme un problème relevant de la sexualité à traiter dans le cadre d'interventions sanitaires et sociales.

Le rapport Liu (Liu et al., 1992 [version chinoise]/Ng, Man-lun, Haeberle EJ, 1997 [traduction anglaise]) est fondé sur une enquête portant sur les comportements sexuels menée en Chine en 1989 et 1990 auprès de 20000 personnes. L'objectif de cette enquête était d'identifier et de clarifier des problèmes liés à la sexualité des personnes en Chine contemporaine. La sexualité des adolescents et des jeunes, le contrôle et la gestion de la sexualité, et la propagation rapide des IST et éventuellement du VIH dans les années 1990 sont énumérés parmi ces problèmes. Bénéficiant du climat politique et social favorable de la fin des années 1980, le «Centre de recherches sociologiques sur la sexualité de Shanghai » dirigé par Liu a organisé cette enquête mise en œuvre dans le cadre d'organisations officielles.

En cette période de réforme et d'ouverture, les troubles sociaux et biologiques associés à la sexualité et la nécessité d'une éducation à la santé sexuelle sont reconnus officiellement et deviennent l'objet d'une prise en charge. Le discours officiel souligne aussi « la nécessité historique de confronter et de résoudre des problèmes difficiles à accepter comme le développement du commerce sexuel et la propagation des IST » (Liu et al., 1992).

À la fin des années 1980, des médecins de Beijing, tels que le $\mathrm{Dr}$ Wu (1988), alors directeur de l'Académie des sciences médicales et le Pr Ruan (1991) de l'université médicale ont contribué à revitaliser la recherche sexologique et deux instituts de recherches sociologiques se sont spécialisés dans les études sur la sexualité depuis une vingtaine d'années ; l'un fut fondé par Liu à Shanghai et l'autre par Pan à Beijing (Institut de recherches sur le genre et la sexualité). En outre, la sexologie est devenu un domaine

\footnotetext{
${ }^{2}$ section révisée de Micollier (2005b).
} 
discret mais dynamique dans la Chine des réformes : selon Pan (1993), le discours scientifique de la sexologie a produit un langage neutre pour l'expression de la sexualité et de l'éducation sexuelle, facilitant la communication dans ce domaine ; il remarque que plus de deux cents livres de sexologie étaient en circulation en 1991 contre seulement six en 1979. Il met en relation la diversification, la visibilité et éventuellement l'augmentation de l'activité sexuelle avec de nombreux facteurs : parmi eux, la transformation de l'habitat lui semble significatif - à savoir l'abandon des maisons de cour au profit d'appartements dans des immeubles où la vie privée est spatialement mieux séparée de la vie collective (Pan, 1993). Ainsi, le mode de vie des familles et des individus s'est privatisé permettant plus d'intimité et une expression plus ouverte de la sexualité. Dans la société traditionnelle, le fondement de la moralité sexuelle s'appuyait sur le contrôle stable et inséparable qu'exerçait le groupe sur l'individu (Pan, 1993).

\section{Conclusion}

Comme le montrent les résultats des enquêtes quantitatives officielles comme le rapport Liu et al. (1992) ou Pan (1993) sur les comportements sexuels ou des études sociologiques plus nuancées et problématisées sur les pratiques et les représentations de la sexualité (par exemple Li, 1998a ; et en particulier son étude qualitative Li, 1998b), il est nécessaire de mettre en évidence les aspects socioculturels et de « contextualiser» les sexualités tout en évitant une « culturalisation » de la sexualité pour optimiser les actions de prévention et de prise en charge face à l'épidémie sexuelle de $\mathrm{VIH} /$ sida.

Par exemple, les acteurs des dispositifs d'intervention ont eu tendance à engager des anthropologues pour étudier des facteurs culturels qui étaient censés éclairer les causes d'échec des interventions sanitaires et sociales. Cependant, l'étude de ces facteurs ne porte ses fruits que si le chercheur s'intéresse simultanément à d'autres facteurs indissociables dans l'analyse (facteurs sociaux, économiques et politiques) et à leurs interrelations. Enfin, une remarque heuristique de portée générale et transculturelle s'impose face aux méthodes et aux modèles des promoteurs d'une éducation à la santé sexuelle qui induirait des changements rapides face à l'urgence épidémique : « ...les changements de comportement en matière de sexualité, ne peuvent être que progressifs... et l'information doit être répétée pour qu'ils soient pérennes. C'est un problème culturel au niveau des messages de prévention : ce n'est pas la culture des populations qui est en cause mais celle de ceux qui communiquent sur la prévention... Il faut absolument que les messages de prévention cessent de culpabiliser les changements progressifs, même s'ils ne sont pas entièrement satisfaisants en termes épidémiologiques » (Vidal, 2000).

En Chine comme ailleurs, l'émergence et la reconnaissance de groupes minoritaires en matière d'orientation sexuelle et de leurs droits même si elle est encore timide et limitée, et la négociation de ces groupes avec d'autres acteurs s'inscrivant dans des cadres normatifs traditionnels (la famille) ou officiels ont été facilitées par les mobilisations collectives face au sida, réponses sociales civiles et officielles même si ces dernières ont été tardives suite à une phase de déni de l'épidémie par les autorités.

Dans le contexte de la prévention et de la prise en charge du VIH/sida en Chine, la notion de «santé sexuelle » a un rôle heuristique dans la production récente, diversifiée et exponentielle d'études sur la sexualité et dans la défense de droits sociaux et individuels. Elle ajoute, en effet, une composante pragmatique bien utile dans la négociation de ces droits avec les acteurs institutionnels officiels voire même incontournable pour que cette discussion ait lieu même s'il faut tout de même remarquer qu'un certain nombre d'études sexologiques, émanant surtout du milieu médical, révèlent une instrumentalisation politique de la notion (Mc Millan, 2006) et cautionnent en dernière analyse des actions et des discours officiels discutables quant à leurs enjeux éthiques et leur efficacité en matière de santé publique. Comme Giami (1996) l'avait montré dans les enquêtes menées dans le contexte du VIH/sida en France, remarquons que, dans ce même contexte en Chine, une « construction épidémiologique de la sexualité » émerge ou s'inscrit en continuité avec l'histoire déjà longue de la modernisation et de la normalisation de la sexualité dans la société chinoise (Dikötter, 1995, 2000), apparaissant comme un nouvel avatar des interférences idéologiques entre la science (représentée ici avec le champ de l'épidémiologie et de la santé publique), la moralité et la sexualité.

\section{Références}

In: Bajos N, Bozon M, Giami A, Dore V, Souteyrand Y, eds. Sexualité et sida. Recherches en sciences sociales. Paris: ANRS, 1995.

In: Broqua C, Souteyrand Y, Lert F, eds. Homosexualités au temps du sida. Tensions sociales et identitaires. Paris: ANRS, 2003.

Bonnet D, Guillaume A. La santé de la reproduction : une émergence des droits individuels. In: Guillaume A, Khlat M, eds. Santé de la reproduction au temps du sida en Afrique. Paris: Ceped, 2004: 11-32.

Bourdieu P. La domination masculine. Paris: Seuil, 1998.

Chen S, Zhang S, Westley SB. HIV/AIDS awareness is improving in China. Asia-Pacific Population Policy, East-West Center: Research Program Population and Health Studies, 2004; (69).

Dikötter F. Sex, culture and modernity in China. Medical science and the construction of sexual identities in the early republican period. London: Hurst, 1995.

Dikötter F. La sexualité et les maladies sexuellement transmissibles en Chine : discours médical et représentations sociales. In: Blanc ME, Husson L, Micollier E, eds. Sociétés asiatiques face au sida. Paris: L'Harmattan, 2000: 23-39.

Giami A. De Kinsey au sida : l'évolution de la construction du comportement sexuel dans les enquêtes quantitatives. Sci Soc Sante 1991; 9(4): 23-56.

Giami A. The influence of an epidemiological representation of sexuality: The ACSF questionnaire. In: Bozon M, Leridon $\mathrm{H}$, eds. Sexuality and social sciences: An analysis of the French Sexual Behavior Survey. London: Dartmouth, 1996: 57-82.

Giami A. Sexual health: the emergence, development, and diversity of a concept. Annu Rev Sex Res 2002; 13: 1-35.

Godelier M. What is a sexual act? Anthropological Theory 2003; 3(2): 179-97.

Haski P. Le sang de la Chine. Quand le silence tue. Paris: Grasset, 2005.

Henriot C. Belles de Shanghaï. Prostitution et sexualité en Chine aux XIX'- $\mathrm{XX}^{\mathrm{e}}$ siècles. Paris: CNRS, 1997. 
In: Herdt G, ed. Sexual Cultures and Migration in the Era of AIDS. Anthropological and Demographic Perspectives. Oxford: Clarendon, 1997.

Hershatter G. Dangerous Pleasures. Prostitution and Modernity in Twentieth Century Shanghaï. Berkeley: University of California Press, 1997.

A human rights in China Report, 1997.

Hinsch B. Passions of the Cut Sleeve. The Male Homosexual Tradition in China. Berkeley: University of California Press, 1990.

Huang Y, Henderson GE, Pan S, Cohen MS. HIV/Risk among BrothelBased Female Sex Workers in China. Sex Transm Dis 2004; 31 (11): 695-700.

Kaufman J, Jing J. China and AIDS. The time to act is now. Nature 2002; 296(5577): 2339.

Kipnis A. 'Face': an adaptable discourse of social surfaces. Positions. East Asia Cultures Critique 1995; 3(1): 119-48.

Liu D, Ng M-l, Zhou L, Haeberle EJ. Zhongguo Dangdai Xing Wenhua : Zhongguo Liangwan Lie 'Xing Wenming' Diaocha Baogao (Contemporary Chinese Sexual Culture: Report of the 'Sex Civilization' Survey on 20000 subjects). Shanghai: Sanlian Bookstore, Chinese Edition, 1992.

Liu Y. The Latest Report from the Homosexual Community on the Mainland. In: Jaivin L, ed. Sex. Chinese Sociology and Anthropology 1994-1995; 27(2): 57-75.

Li Y, Wang X. Tamende shijie: Zhongguo nan tongxinglian qunluo toushi (Leur monde : radioscopie des communautés homosexuelles masculines en Chine). Hong Kong: Tiandi tushu youxian gongsi, 1992.

Li Y. Tongxinglian ya wenhua (Sous-cultures homosexuelles). Beijing: Jinri zhongguo chubanshe, 1998.

Li Y. Zhongguo nuxing de ganqing yu xing (L'amour et la sexualité des femmes chinoises). Beijing: Jinri zhongguo chubanshe, 1998.

Long N. Development sociology. Actor perspectives. London and New York: Routledge, 2001.

McMillan J. Sex, science and morality in China. London and New York: Routledge, 2006.

In: Micollier E, ed. Sexual cultures in East Asia. The social construction of sexuality and sexual risk in a time of AIDS. London and New York: RoutledgeCurzon, 2004.

Micollier E. Acteurs de la mobilisation collective contre le sida en Chine et solidarités transnationales : dynamiques locales et visibilité des groupes de défense des minorités sexuelles et sociales. Face à face. Regards sur la santé 2005a; 7 (revue bilingue en ligne, www.ssd.u-bordeaux2.fr/faf) : 31-40.

Micollier E. Le sida en Chine : pratiques et discours de la sexualité. Perspectives chinoises 2005b; 89 (revue bilingue, accès en ligne, www.cefc.com.hk) : 2-15.

Pan S. A sex revolution in current China. J Psychol Human Sex 1993; 6: 1-14.

Pan S. Homosexual behaviors in contemporary China. J Psychol Human Sex 1995; 7(4): 1-17.

Pan S. Male homosexual behavior and HIV-related risk in China. In: Aggleton P, ed. Bisexuality and AIDS: international perspectives. London: Taylor-Francis Group, 1996: 178-90.

Pan S. Zhongguo dixia 'xing changye' kaocha (Investigation sur l'industrie du sexe souterraine en Chine). Beijing: Qunyan chubanshe, 1999.
Pan S. Three 'Red Light Districts' in China. In: Micollier E, ed. Sexual cultures in East Asia. The social construction of sexuality and sexual risk in a time of AIDS. London and New York: RoutledgeCurzon, 2004: 23-53.

Rofel L. Qualities of desire: imagining gay identities in China. Gay Lesbian Quarterly 1999; 5(4): 451-74.

Rogers SJ, Ying L, Fung K, Kaufman J. Reaching and Identifying the STD/HIV Risk of Sex Workers in Beijing. AIDS Educ Prev 2002; 2(14): 217-27.

Rosenthal E. AIDS and Corruption in a poor Chinese province. International Herald Tribune, 2001; [May 31 (New York Times, May 28)].

Ruan F. Sex in China. Studies in sexology in Chinese culture. New York: Plenum, 1991.

Sang Tze-lan D. The emerging lesbian. Female same-sex desire in modern China. Chicago: University of Chicago Press, 2003.

UNAIDS. HIV/AIDS : China titanic peril. 2002; (89 p.).

UNAIDS. A joint assessment of HIV/AIDS prevention, treatment and care in China. 2003; (Dec.1., 40 p.).

UNAIDS. A joint assessment of HIV/AIDS prevention, treatment and care in China. 2004; (Dec.1., 30 p.).

UNAIDS. 2005 Update on the HIVIAIDS epidemic and response in China. MoH, PRC Joint UN Program on HIV/AIDS. WHO, 2006; (13 p.).

Vidal L. Sexualité et sida en Afrique : prévention et évolution des recherches. In: Bazin L, Mendès-Leite R, Quimimal C, eds. Déclinaisons anthropologiques des sexualités. Journal des Anthropologues, 2000: 82-3; (309-23).

Vitiello G. Asians of the Same Intent. IIAS Newsletter 2002; 29: 6.

Xinhua (agence de presse Chine nouvelle). Research shows Premarital Sex prevalent in China. Oct. 10. 2003; (Statistics released by The Chinese Family Planning Association).

Zheng L-H. Les Chinois de Paris et leurs jeux de face. Paris: L'Harmattan, 1995.

Wan Y. Fulu: Zhongguo dalu tongzhi de xiankuang (Appendice: la situation actuelle des homosexuels de Chine continentale). In: Zhou $\mathrm{H}$, ed. Beijing tongzhi gushi (Histoires de " camarades » de Pékin). Xianggang (Hong Kong): Xianggang tongzhi yanjiushe, 1996: 167-88.

Wan Y. Becoming a Gay Activist in Contemporary China. In: Sullivan G, Jackson P, eds. Gay and Lesbian Asia: Culture, Identity, Community. New York: Haworth, 2001.

In: Wu J, ed. Xing Yixue (Sexologie médicale). Wenxian: Kexue jishu chubanshe, 1988.

Zhou H. Beijing tongzhi gushi. Xiangkang: Xiangkang tongzhi yanjiushe, 1996.

Zhou H. Histoires de "camarades": les homosexuels en Chine. Paris: Paris-Méditerranée, 1997; (postface : Wu, Garry, traducteurs : Lee F, Marek MT).

Zhou H. Tongzhi: Politics of Same-Sex Eroticism in Chinese Societies. New York: Haworth, 2000; (Chou Wah-shan).

Zhou H. Homosexuality and the Cultural Politics of Tongzhi in Chinese Societies. In: Sullivan G, Jackson PA, eds. Gay and Lesbian Asia: Culture, Identity, Community. New York: Haworth, 2001; (Chou Wah-shan). 